\title{
Enhancing the Potentiality of Trichoderma harzianum against Pythium Pathogen of Beans Using Chamomile (Matricaria chamomilla, L.) Flower Extract
}

\author{
Abeer Abdulkhalek Ghoniem ${ }^{1}$, Kamar M. Abd El-Hai ${ }^{2}$, Ayman Y. El-khateeb ${ }^{3}$, Noha M. Eldadamony ${ }^{4}$, \\ Samy F. Mahmoud ${ }^{5}\left(\mathbb{D}\right.$ and Ashraf Elsayed ${ }^{6, *(\mathbb{D})}$
}

\section{check for}

updates

Citation: Ghoniem, A.A.; Abd El-Hai, K.M.; El-khateeb, A.Y.;

Eldadamony, N.M.; Mahmoud, S.F.; Elsayed, A. Enhancing the

Potentiality of Trichoderma harzianum against Pythium Pathogen of Beans Using Chamomile (Matricaria chamomilla, L.) Flower Extract. Molecules 2021, 26, 1178. https:// doi.org/10.3390/molecules26041178

Academic Editor: Francesco Epifano

Received: 6 February 2021

Accepted: 19 February 2021

Published: 22 February 2021

Publisher's Note: MDPI stays neutral with regard to jurisdictional claims in published maps and institutional affiliations.

Copyright: (C) 2021 by the authors Licensee MDPI, Basel, Switzerland. This article is an open access article distributed under the terms and conditions of the Creative Commons Attribution (CC BY) license (https:/ / creativecommons.org/licenses/by/ $4.0 /)$.
1 Microbial Activity Unit, Department of Microbiology, Soils, Water and Environment Research Institute, Agricultural Research Center, Giza 12619, Egypt; abeer.abdelkhalik@yahoo.com

2 Department of Leguminous and Forage Crop Diseases, Plant Pathology Research Institute, Agricultural Research Center, Giza 12112, Egypt; Kamar_1968@yahoo.com

3 Department of Agricultural Chemistry, Faculty of Agriculture, Mansoura University, Elgomhouria St., Mansoura 35516, Egypt; aymanco@mans.edu.eg

4 Seed Pathology Department, Plant Pathology Institute, Agricultural Research Center, Giza 12112, Egypt; Nohamohamadt@gmail.com

5 Department of Biotechnology, College of Science, Taif University, P.O. Box 11099, Taif 21944, Saudi Arabia; s.farouk@tu.edu.sa

6 Botany Department, Faculty of Science, Mansoura University, Elgomhouria St., Mansoura 35516, Egypt

* Correspondence: ashraf-badawy@mans.edu.eg

\begin{abstract}
Our present study was designed to investigate the role of both Trichoderma harzianum and chamomile (Matricaria chamomilla L.) flower extract in mutual reaction against growth of Pythium ultimum. In vitro, the activity of chamomile extract was found to reduce the radial growth of Pythium ultimum up to $30 \%$ compared to the control. Whereas, the radial growth reduction effect of T. harzianum against P. ultimum reached $81.6 \%$ after $120 \mathrm{~h}$. Data also showed the productivity of total phenolics and total flavonoids by T. harzianum, was 12.18 and $6.33 \mathrm{mg}$ QE/100 mL culture filtrate, respectively. However, these compounds were determined in chamomile flower extract at concentrations of 75.33 and $24.29 \mathrm{mg} \mathrm{QE} / 100 \mathrm{~mL}$, respectively. The fractionation of aqueous extract of chamomile flower using HPLC provided several polyphenolic compounds such as pyrogallol, myricetin, rosemarinic acid, catechol, $p$-coumaric acid, benzoic acid, chlorogenic acid and other minor compounds. In vivo, the potentiality of T. harzianum with chamomile flower extract against Pythium pathogen of bean was investigated. Data obtained showed a reduction in the percentage of rotted seed and infected seedling up to $28 \%$ and $8 \%$, respectively. Whereas, the survival increased up to $64 \%$ compared to other ones. There was also a significant promotion in growth features, total chlorophyll, carotenoids, total polyphenols and flavonoids, polyphenol-oxidase and peroxidase enzymes compared to other ones. To the best of our knowledge, there are no reported studies that included the mutual association of fungus, T. harzianum with the extract taken from the chamomile flower against $P$. ultimum, either in vitro or in vivo. In conclusion, the application of both T. harzianum and/or M. chamomilla extracts in the control of bean Pythium pathogen showed significant results.
\end{abstract}

Keywords: Trichoderma harzianum; antifungal activity; Matricaria chamomilla; Phaseolus vulgaris

\section{Introduction}

Leguminous crops, such as Phaseolus vulgaris, L. are widely cultivated for human consumption, due to their richness in protein, fibers, calories, vitamin B and other minerals, e.g., iron, calcium, phosphorous and zinc [1,2]. Common French beans are a variant of those legume crops that contain several constituents, i.e., flavonoids, saponins, tannins and phenolic acid, with significant biological activity, e.g., anti-urolithiatic and anti-obesity [3]. However, these bean plants often get infected by pathogenic species of Pythium spp., which 
cause decay, pre-emergency and post-emergency on bean species. Additionally, the infected common bean seeds or seedlings turned to be discolored, chlorotic and soft and decay after germination and/or they become wilt or die within 1-3 weeks [4].

Several pathogens are known to infect been plants and have a significant economic impact on the bean market. The most aggressive species of Pythium, P. aphanidermatum, affects bean plants causing root rot and crown necrosis of mature bean plants, which has a significant economic impact $[5,6]$. Another species is $P$. splendens, which is known for its pathogenicity towards seedlings of different species, causing damping-off of seedlings [7]. The most common Rhizoctonia solani, Fusarium solani, F. oxysporum and Pythium ultimum had superiority among the soil borne fungi in causing pathogens of beans [8]. Importantly, several investigations pointed out that the colored seeds of beans cultivars were more resistant to Pythium pathogens compared to other white seeds [9]. Therefore the choice in procedures of pathogen control, which have differing environmental impact, depends on the type of the bean cultivars and their resistance which has an effect on sustaining the agricultural process.

Sustaining the agricultural process with a high crop production, requires protection strategies of which disease control plays a crucial role in the management and protection against plant diseases which cause severe loss of crop during epidemics [10]. Fungicides and pesticides are commonly used to combat fungal and insect diseases. However, their active chemical agents often have deleterious effects on the environment so the search for environmentally friendly alternatives has become significant.

The biological control of these diseases using Trichoderma spp. has been gaining interest worldwide [11], due to the reported efficacy and potential of Trichoderma spp against soil borne fungi [12]. Members of the Trichoderma genus of fungi belong to the family Hypocreaceae, which is present in nearly all soil types. They are the most prevalent culturable fungi and can be characterized as opportunistic avirulent plant symbionts that can form mutualistic endophytic relationships with several plant species [13]. The therapeutic bioagent, Trichoderma spp. employs numerous mechanisms involved in the restriction of other fungi including enhanced promotion of plants through the vegetation period of growth. Examples of such mechanisms involved include mycoparasitism, antibiosis activity, competition, chitinase and gluconase enzymes production $[14,15]$ additionally, the defense responses with metabolism of germination stimulants and promotion of systemic acquired resistance $[10,16,17]$. Other studies showed that Trichoderma spp are able to secrete several biologically active agents of significance, e.g., pyrones, isocyanates, peptides, peptaibols and trichothenes [18]. Trichoderma spp. are promising new therapeutic agents as they are potentially safer and effective than commercially available alternatives in addition to being more environmentally safer posing relatively no hazardous effect to food chains [19].

Plant extracts are considered another alternative to traditional fungicides and pesticides as they produce bioagents that are effective against bacteria and fungi [20]. The volatile compounds and essential oils show promise as a substitute for antibacterial and antifungal agents in several studies [21]. Additionally, increasing attention has been directed towards extracts of grapefruit and citrus wastes which contain bioactive molecules that have anti-fungal properties as well as the ability to further induce plant resistance [22,23]. Similarly, the biological activity of Capparis spinosa has been investigated, by which the scavenging activity against DPPH and ABTS radical cations could be due to the high content of phenolic compounds such as flavonoids and tannins [24]. Najjaa, et al. [25] investigated the high content of polyphenol (164.85 GEA/g extract) of herbal plant, i.e., Retama reatam, which has antimicrobial properties. Chamomile is one of the most consumed herbal teas in the world extracted from chamomile (Matricaria chamomilla, L.) which is used in therapeutic spectrums, e.g., anti-inflammatory, analgesic, antimicrobial, antispasmic and sedative [26]. The therapeutic use of the chamomile is due to it being an excellent source of bioactive molecules such as phenolic, terpenoids, essential oil and flavonoids content $[27,28]$. Moreover, the high content of phenolic compounds, especially the subfam- 
ily of flavonoids are the most responsible for its high antioxidant activity which can be utilized through extraction from chamomile plants [29].

The extraction strategies for phytonutrients of chamomile could be subjected to several techniques, of which several employ the use of environmentally safe and nontoxic solvents [30]. In general, the extraction of various phytochemicals, specifically polyphenolic compounds is effectively done by solvents such as methanol, ethanol, glycerol and water [31]. However, more and more attention has been focused towards the use of water as a safe effective solvent for the extraction of phenolic compounds [32].

This study has been designed to investigate the potentiality of $T$. harzianum towards P. ultimum, in association with aqueous extract of chamomile (Matricaria chamomilla, L.) flower, either in vitro and/or in vivo.

\section{Results and Discussion}

Generally, the bean is regarded as an important nutritional crop in combating starvation for millions of people worldwide [33,34], but it is prone to diseases throughout its life cycle, especially ones that are caused by soil borne fungi [35]. Fungicide threshold chemical agents are often used to effectively protect plants from soil borne diseases, however their use is restricted due to their immensely harmful effect on the environment leading to the emergence of mutant fungal variations of pathogenic species as well as biomagnification that extends to human food products affecting their health [36,37]. Recently, both biotic and naturally occurring abiotic agents have shown to be the best approaches in perspective study plant disease control, due to their relative safety towards the environment. In this study, T. harzianum alone and/or associated with chamomile (Matricaria chamomilla, L.) flower extract was investigated against the bean (Phaseolus vulgaris, L.) pathogen P. ultimum, in vitro and in vivo.

\subsection{In Vitro, the Comparative Response of P. ultimum to Aqueous Extract of Chamomile Flower} and T. harzianum

Our study was done to evaluate the potentiality of chamomile flower extract on the radial growth of P. ultimum. Data shown in Figure 1 indicates the superiority of chamomile extract at concentrations of $3.0 \%$, compared to other treatments where the radial growth of P. ultimum decreased significantly to $30 \%$ compared to the control. The radial growth of $P$. ultimum responded significantly to different concentrations of chamomile extract when compared to the control. These results could be due to the total phenolic compounds and total flavonoids, 75.33 and $24.29 \mathrm{mg}$ QE/100 mL filtrate, respectively contained in chamomile.

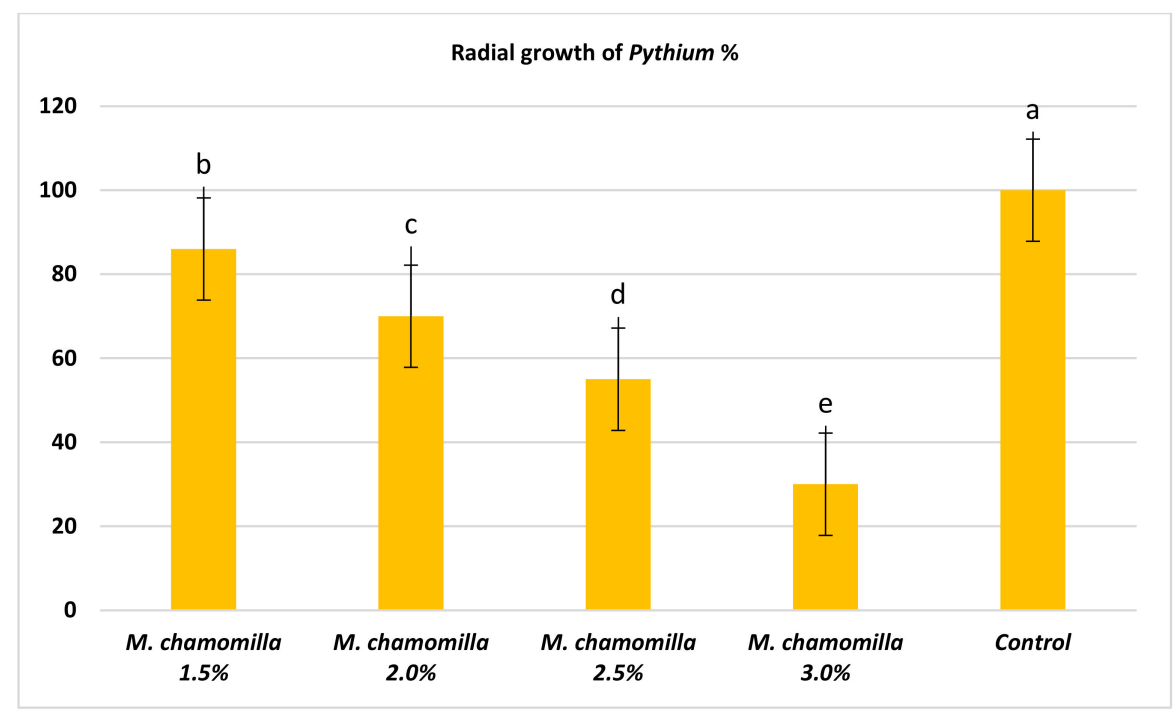

Figure 1. Radial growth (\%) of P. ultimum as a responded to thresholds of chamomile flower extract. 
Constituents of chamomile flower extract (Table 1), were determined during the fractionation of the aqueous extract of chamomile using high performance liquid chromatography (HPLC showing several common phenolic compounds, such as myricetin (1587.82 ppm), quercetin (927.72 ppm), benzoic acid (414.88 ppm), rosemarinic acid (370 ppm), which were provided as major constituents. Other components showed minor values, e.g., catechol (11.28 ppm), coumaric acid (23.59 ppm) and chlorogenic acid (38.02). These results are consistent with other reported studies [26,28]. Likewise, Raal et al. [27] investigated the essential oil, terpenoids and polyphenols content in commercial chamomile extract. Polyphenolic compounds and their derivatives could be play a crucial role as an alternative to antifungal activity [38]. However, it is interestingly that, the chamomile extract was found to significantly sustain the growth features of T. harzianum, i.e., the fresh weight and number of spores compared to the control (Figure 2). However, the dry weight showed no significant difference compared to the control. Consequently, the chamomile flower extract was chosen as applicable bioactive agent in association with T. harzianum in the management of Pythium pathogen in vivo. The antagonistic activity of T. harzianum against $P$. ultimum during a dual culture procedure was studied, by which the radial growth of P. ultimum decreased significantly with a ratio of $81.6 \%$, after $120 \mathrm{~h}$ compared to the control (Figure 3). There is also a significant difference among the interval periods.

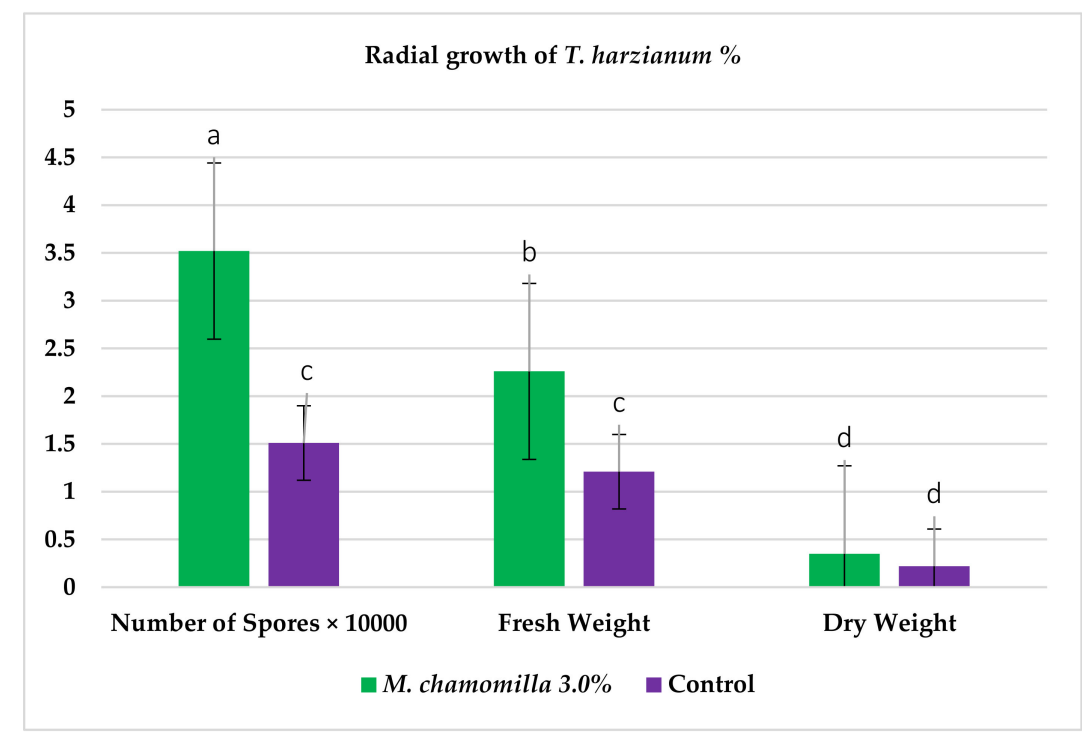

Figure 2. Enhancement of the radial growth of T. harzianum as threshold of chamomile flower extract compared to the control.

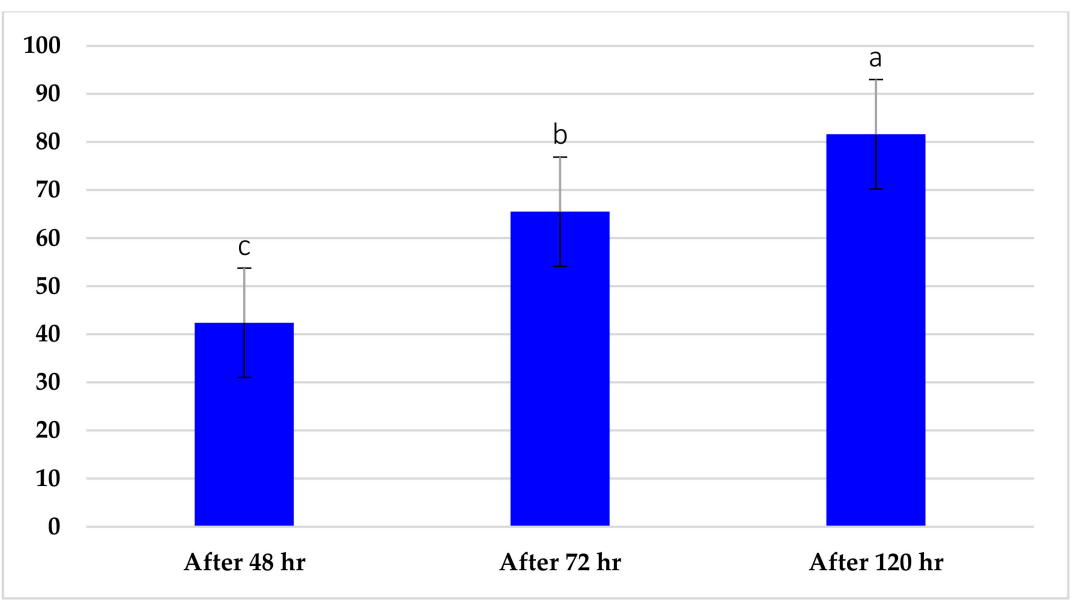

Figure 3. Growth reduction percentage of P. ultimum as antibiosis of T. harzianum. 
Table 1. Fractionation and identification of phenolic compounds of Matricaria chamomilla flowers extract using HPLC technique.

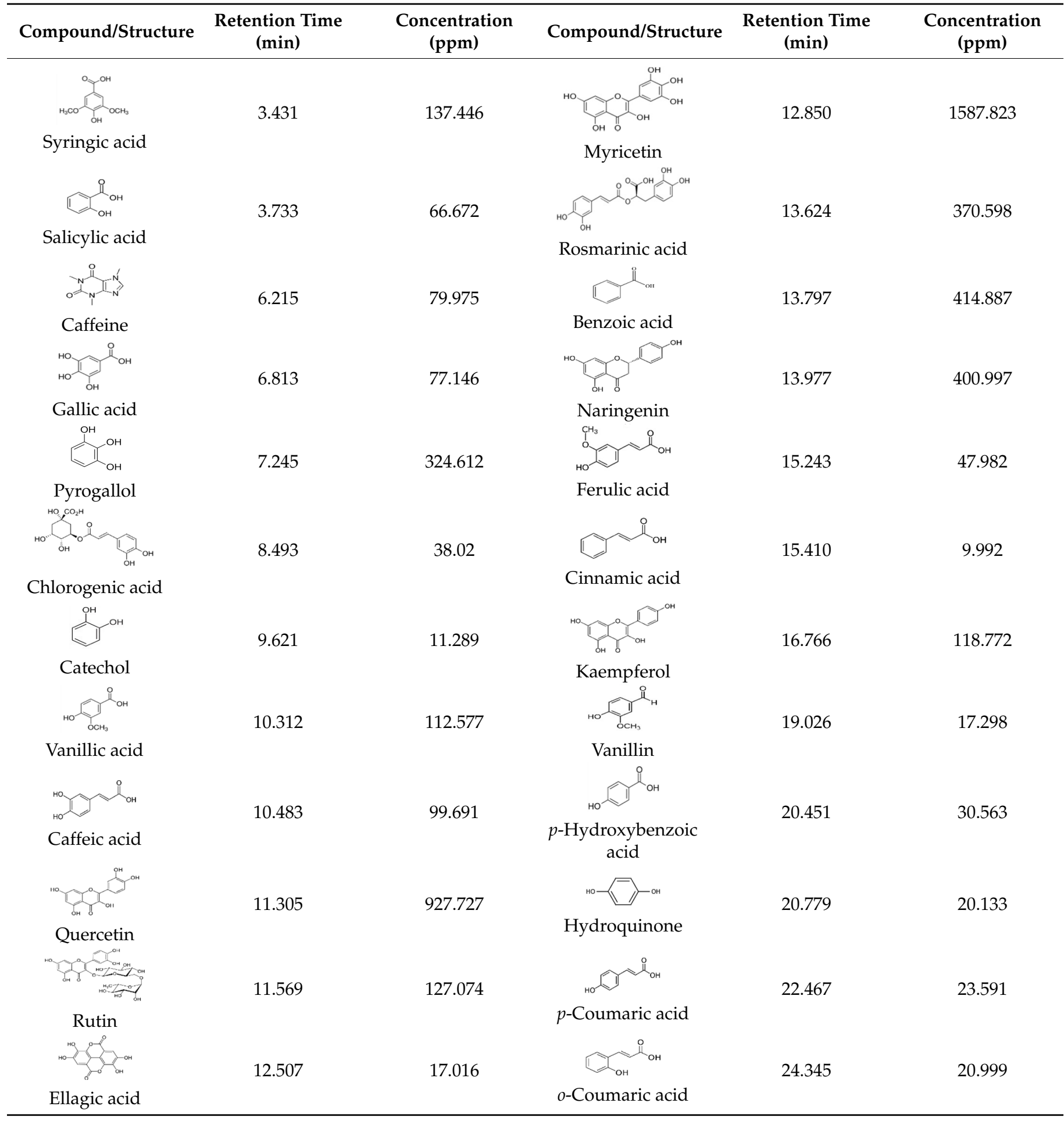

The total phenolic compounds and total flavonoids content of culture filtrate of $T$. harzianum were 12.18 and $6.33 \mathrm{mg} Q E / 100 \mathrm{~mL}$ culture filtrate, respectively. Furthermore, the kinetic process of how the Trichoderma spp. preys on the host pathogen, could be occurred during the mycoparasitic interaction, by secretion of chitinase and $\beta$-1,3-glucanase lytic enzymes that attack the host fungi bearing holes in the walls of the fungi and plucking the nutrients which reduces their growth [39]. Moreover, the potentiality of Bacillus pumilus INR7, Trichoderma harzianum and Rhizophagus intraradices against Rhizoctonia root rot of 
common bean (Phaseolus vulgaris, L.) has been investigated, in addition to their extended efficiency at the reduction of disease severity and improving dry weight of the bean [40]. The potentiality of Trichoderma spp. towards some pathogenic fungi, e.g., Alternaria alternata, Macrophomina phaseolina and Geotrichum candidum was investigated. T. viride was found to reduce the fungal growth of A. alternata, M. phaseolina and G. candidum up to $84.44 \%$, $86.66 \%$ and $74.44 \%$ respectively [41]. Similarly, the Rhizobium sp along with cyanobacterial extracts significantly inhibited the mycelial growth of Sclerotinia sclerotiorum that causes the white rot disease of the common bean [42].

\subsection{In Vivo, Investigation of the Potentiality of Chamomile Flower Extract and Culture of T. Harzianum Against Pythium Pathogen of Bean}

\subsubsection{Disease Assessment}

The percentage of rotted seeds and infected seedlings as well as the survival of Phaseolus vulgaris plants as they responded to different treatments were recorded in Table 2 across the board the bean pathogen disease incidence $\%$ was decreased significantly in all treatments. a combined mixture of chamomile flower extract and T. harzianum showed the most promise and rose to second order after fungicide, with a highly significance increase of rotted seed, infected seedling and survival percentages. However, the fungicide increased the survival percent up to $84 \%$, whereas, both of chamomile extract and $T$. harzianum increased the survival percentage of beans by 58 and 54\%, respectively. The survival percentages of beans were significantly responsive to therapeutic treatments, and this response is likely due to the presence of flavonoids and phenolics compounds in the extract and/or associated with growth of fungus, Trichoderma spp [38]. Negi et al. [15] investigated the role of T. viride, T. harzianum and T. virens as bioagents against Phaseolus vulgaris diseases, in which the Trichoderma spp antagonized many of the plant pathogens, additionally, they served a role as plant growth promoters. The efficiency of plant growth promoting rhizobacteria play a crucial role in protection of Phaseolus vulgaris beans against fungal diseases [15]. Similarly, the synergism of cyanobacterial extracts with Rhizobium leguminosarum diminished the disease incidence and severity in common bean (Phaseolus vulgaris, L.) during infection with Sclerotinia sclerotiorum [42]. The chamomile flower extract was effective but less efficient compared to the mixture of extract with T. harzianum in disease parameters. The efficiency of chamomile extract is likely due to the involvement of antioxidant compounds, e.g., flavonoids, coumarins, phenolic acids, glucosides, terpenoids, vitamins and sesquiterpenes $[26,27]$. The efficacy of Trichderma harzianum C52 in reducing the disease percentage and disease incidence of lettuce, was 50 and 35\%, respectively [43]. McLean, et al. [44] investigated the role of Trichoderma harzianum C52 in controlling the onion white rot pathogen, Sclerotium cepivorum.

Table 2. The percentage of rotted seeds and infected seedlings as well as survival plants of Phaseolus vulgaris as response to different treatments.

\begin{tabular}{cccc}
\hline Treatments & Rotted Seeds & Infected Seedling & Survival\% \\
\hline$M$ & $30 \mathrm{~b}$ & $12 \mathrm{a}$ & $58 \mathrm{bc}$ \\
T. harzianum & $38 \mathrm{~b}$ & $8 \mathrm{ab}$ & $54 \mathrm{bc}$ \\
$T+M$ & $28 \mathrm{~b}$ & $8 \mathrm{ab}$ & $64 \mathrm{~b}$ \\
Fungcide & $12 \mathrm{c}$ & $4 \mathrm{~b}$ & $84 \mathrm{a}$ \\
Pythium & $56 \mathrm{a}$ & $14 \mathrm{a}$ & $30 \mathrm{~d}$ \\
Ex + Pythium & $32 \mathrm{~b}$ & $12 \mathrm{a}$ & $64 \mathrm{~b}$ \\
T+M + Pythium & $38 \mathrm{~b}$ & $12 \mathrm{a}$ & $50 \mathrm{bc}$ \\
T+ Pythium & $40 \mathrm{~b}$ & $16 \mathrm{a}$ & $44 \mathrm{~cd}$ \\
\hline
\end{tabular}

Different letters within each column means values are significantly different at $p \leq 0.05$.

\subsubsection{Morphological Features of Bean Plants}

Data as depicted in Figure 4 illustrated the values of plant length (root and shoot length), root fresh weight, root dry weight and plant dry weight, as well as, leaf area as the samples responded to different treatments. Concerning plant length of beans, chamomile 
extract showed a high value of length compared to other treatments, however no significant difference of length values were found with the use of fungicide and a mixture treatment (extract and T. harzianum). Furthermore, the chamomile extract showed superiority in root fresh weight, with significant value increases compared to the other treatments with no significant difference among the mixture, fungicide and T. harzianum treatments in plant fresh weight. Regarding leaf area, the fungicide showed the highest values followed by the mixture and chamomile, respectively. Similarly, the efficiency of both Bacillus subtilis ATCC11774 with and/or without amino acids mixture against wilt disease pathogen of tomato has been investigated, by which the response in plant growth features, e.g., root and shoot length, shoot fresh and dry weight of tomato plants to Bacillus subtilis with a mixture of amino acids was occupied [45]. As well as, the management of tomato leaf spots caused by the fungus Alternaria tenuissima, by the use of the bioagents Agrileen and salicylic acid were tested [46].

\subsubsection{Physiological Characters}

- Total phenols, total flavonoids, defense related enzymes and antioxidant capacity

The response of total phenols, flavonoids and defense related enzymes (polyphenol oxidase and peroxidase), as well as, antioxidant capacity (ABTS\% inhibition and $\mathrm{DPPH} \%$ inhibition) to chamomile extract, T. harzianum and its combination under non-infested and infested soil with P. ultimum are shown in Table 3. Concerning total polyphenols, the mixture treatment showed higher values when compared to other treatments, whereas, both chamomile and T. harzianum provided higher values compared to Pythium treatment alone. The tricombination (extract+Tricho.+ Pythium) showed the highest value compared to each individual extract and Trichoderma alone. Interestingly, the mixture of extract and Trichoderma provided the highest values of total flavonoids significantly higher than other treatments. Additionally, there was an increase in responsiveness shown in values of treatments using polyphenol oxidase and peroxidase compared to Pythium alone. Otherwise, the ABTS and DPPH inhibition\% were increased significantly in case of a mixture, followed by fungicide, whereas in a case of Pythium alone, a less value has been obtained compared to other ones. These data are conceding with the investigation of Ghoniem, et al. [45] who found that an increased response of total polyphenols, total flavonoids, and polyphenoloxidase in tomato plants as result of Bacillus subtilis and a mixture of amino acids. Further, Trichoderma spp. could be produced effectively plant growth promoters, such as gibberellic acid and biological control of some pathogenic fungi, i.e., Rhizoctonia solani, with increasing the plant growth $[47,48]$.

Table 3. Biochemical features of Phaseolus vulgaris plants as response of different treatments.

\begin{tabular}{|c|c|c|c|c|c|c|}
\hline Treatment & $\begin{array}{c}\text { Total } \\
\text { Polyphenols }\end{array}$ & $\begin{array}{c}\text { Total } \\
\text { Flavonoids }\end{array}$ & $\begin{array}{c}\text { Polyphenol } \\
\text { Oxidase }\end{array}$ & Peroxidase & $\begin{array}{c}\text { ABTS } \\
\text { Inhibition } \%\end{array}$ & $\begin{array}{c}\text { DPPH } \\
\text { Inhibition \% }\end{array}$ \\
\hline M. chamomilla & $28.699 \mathrm{~d}$ & $15.056 \mathrm{~d}$ & $9.776 \mathrm{~d}$ & $0.619 \mathrm{~d}$ & $29.936 \mathrm{~d}$ & $13.677 \mathrm{e}$ \\
\hline T. harzianum & $27.755 \mathrm{~d}$ & $14.189 \mathrm{~d}$ & $9.414 \mathrm{~d}$ & $0.599 \mathrm{~d}$ & $21.726 \mathrm{e}$ & $11.495 \mathrm{f}$ \\
\hline$T+M$ & $43.222 \mathrm{a}$ & $28.469 \mathrm{a}$ & $15.353 \mathrm{a}$ & $0.948 \mathrm{a}$ & $58.234 \mathrm{a}$ & $26.151 \mathrm{a}$ \\
\hline Fungcide & $40.960 \mathrm{~b}$ & $26.381 \mathrm{~b}$ & $11.152 \mathrm{c}$ & $0.897 \mathrm{~b}$ & $55.647 \mathrm{~b}$ & $25.036 \mathrm{~b}$ \\
\hline Pythium & $26.071 \mathrm{e}$ & $12.632 \mathrm{e}$ & $8.766 \mathrm{e}$ & $0.561 \mathrm{e}$ & $14.129 \mathrm{~g}$ & $7.147 \mathrm{~h}$ \\
\hline$M+P y$ thium & $32.945 \mathrm{c}$ & $18.980 \mathrm{c}$ & $11.408 \mathrm{c}$ & $0.716 \mathrm{c}$ & $33.658 \mathrm{c}$ & $17.919 \mathrm{~d}$ \\
\hline$T+M+$ Pythium & $40.079 \mathrm{~b}$ & $25.575 \mathrm{~b}$ & $14.150 \mathrm{~b}$ & $0.877 \mathrm{~b}$ & $34.495 \mathrm{c}$ & $19.557 \mathrm{c}$ \\
\hline
\end{tabular}



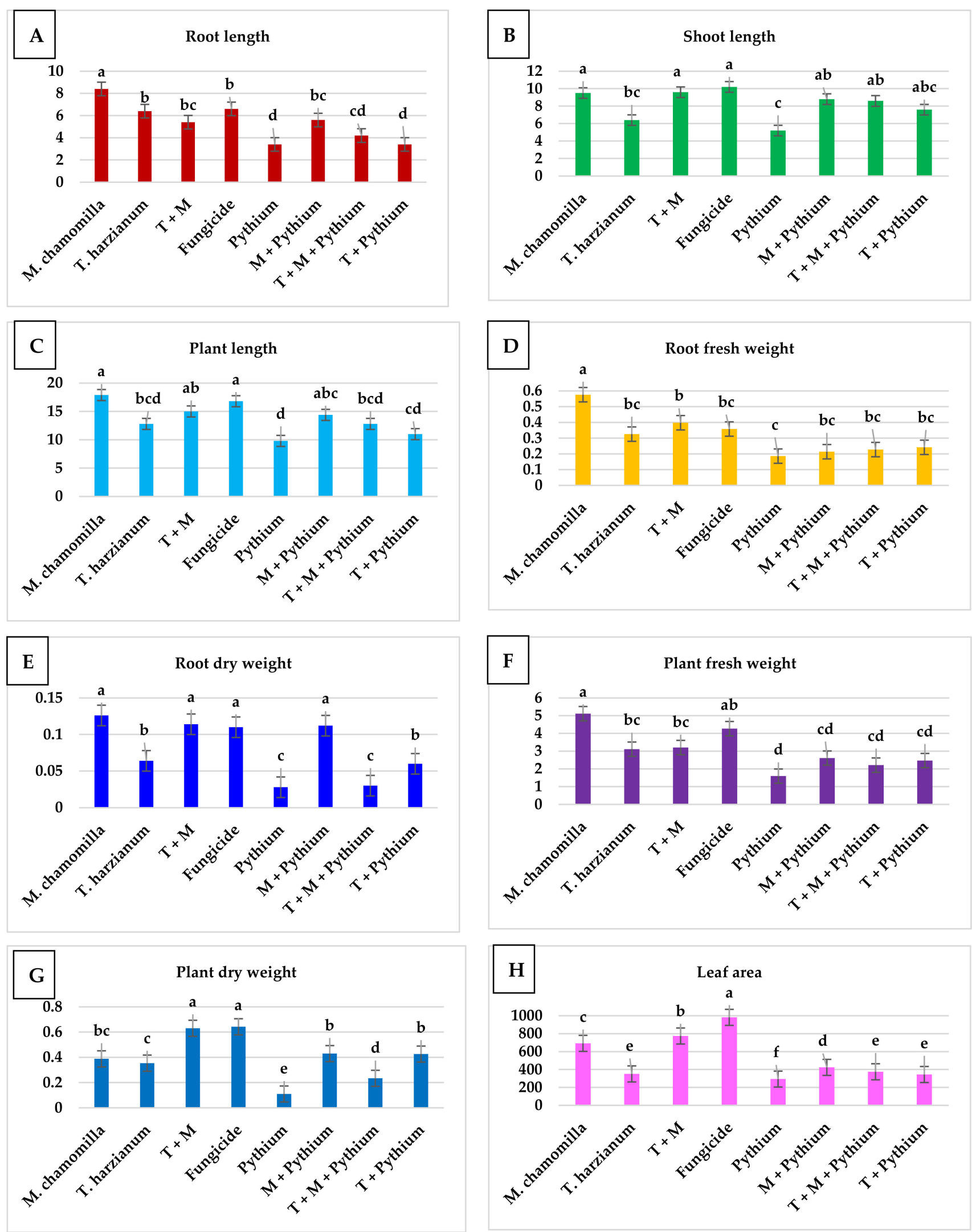

Figure 4. (A) root length, (B) shoot length, (C) plant length (D) root fresh weight, (E) root dry weight, (F) plant fresh weight and $(\mathbf{G})$ plant dry weight, as well as, $(\mathbf{H})$ leaf area of Phaseolus vulgaris as response to different treatments. 
Our results implicated that the content of chamomile extract of phenols and flavonoids, as well as, the productivity of such these a aforementioned compounds by T. harzianum could be responsible for anti-fungal activity, modulators of pathogenicity and activators of plant defense [38]. Another reported study of Žlabur et al. [26] investigated the bioactive components of chamomile extract, such as flavonoids, coumarins, phenolic acids, glucosides, sesquiterpenes and antioxidant vitamin, in addition to antioxidant activity with toxicity against Vibrio fischeri [28]. Other investigations pointed out that the exogenously applicable of biotic and abiotic agents could be affecting the physiological and metabolites of host plants, during activation of defense gene and generation of some antioxidant substances [46,49]. Likewise, the Trichoderma spp. (e.g., T. hamatum, T. viride, and T. harzianum) were showed to reduced significantly the pre-and post-emergence damping off disease of bean under artificial infection with pathogens [50], with additional significant increase in bean plant features and peroxidase and poly phenol oxidase activities compared to the control.

Commonly, the knowledge concerning the behavior of how Trichoderma spp. antagonism P. ultimum, is a vital for management of bean disease pathogen, whereby there are several mechanisms were suggested, i.e., production of lytic enzymes, antifungal antibiotics, competitors with pathogens and promotion of plant growth [51]. As well as, the potentiality of some Trichoderma spp against pathogenic fungi could be due to production of secondary metabolites such as, pyrones, koninginins, viridian, gliovirin, peptaibols and other negligible constituents [52].

- Photosynthesis pigments

Total chlorophyll, chlorophyll a, chlorophyll b and carotenoids were determined in Table 4. Generally, P. ultimum-infested soil decreased the total chlorophyll contents in kidney bean leaves significantly compared to the other pathogens. Furthermore, the mixture of extracts and Trichoderma showed superiority with significant values in total chlorophyll compared to the other treatments. Additionally, the carotenoid content of leaves showed a significant increase as a response to treatments compared to Pythium alone. These results follow those of reported investigations, which showed the role of Trichoderma harzianum in increasing the total chlorophyll content in potato, in addition to increasing antioxidant enzymes [47]. Moreover, Pseudomonas aeruginosa KMPCH and rhizobacteria showed a vital role in induction of systemic resistance in bean [10]. The Trichoderma spp. were also found to be effective against enormous soil borne fungi, especially their ability to induce plant resistance against foliar disease pathogen in bean, such as Uromyces appendiculatus [10], additionally, production of some antifungal agents, e.g., cellobiohydrolase, $\mathrm{N}$-acetyl- $\beta$-glucosaminidase, trypsin like protease and $\beta$-glucosidase [53].

Table 4. Chlorophyll A, chlorophyll B and total chlorophyll of Phaseolus vulgaris plants as responded to different treatments.

\begin{tabular}{ccccc}
\hline Treatment & Chlorophyll A & Chlorophyll B & Total Chlorophyll & Carotenoids \\
\hline M. chamomilla & $2.814 \mathrm{a}$ & $1.651 \mathrm{~b}$ & $4.466 \mathrm{~b}$ & $0.679 \mathrm{c}$ \\
T. harzianum & $2.123 \mathrm{~b}$ & $1.418 \mathrm{c}$ & $3.542 \mathrm{~d}$ & $0.578 \mathrm{~d}$ \\
T $+M$ & $2.908 \mathrm{a}$ & $1.875 \mathrm{a}$ & $4.784 \mathrm{a}$ & $0.934 \mathrm{a}$ \\
Fungcide & $1.592 \mathrm{~d}$ & $1.180 \mathrm{e}$ & $2.771 \mathrm{f}$ & $0.529 \mathrm{e}$ \\
Pythium & $1.526 \mathrm{~d}$ & $1.113 \mathrm{e}$ & $2.639 \mathrm{f}$ & $0.286 \mathrm{f}$ \\
M Pythium & $2.136 \mathrm{~b}$ & $1.430 \mathrm{c}$ & $3.566 \mathrm{~d}$ & $0.894 \mathrm{~b}$ \\
$T+$ M Pythium & $2.248 \mathrm{~b}$ & $1.598 \mathrm{~b}$ & $3.846 \mathrm{c}$ & $0.597 \mathrm{~d}$ \\
\hline
\end{tabular}

Different letters within each column means values are significantly different at $p \leq 0.05$.

\subsubsection{Disease Symptoms of Bean (Phaseolus vulgaris, L.) as Pythium Pathogen Infection}

In infected soil, the disease symptoms appeared as necrotic lesions on vegetative growth, root rot, lower stem rot, wilt and subsequent plant death before the flower stage. Figure 5 illustrates the clear differences of kidney bean root structure that were found among cross sections under scanning electron microscope (SEM) of normal plant 
(Figure 5A) and plant infected with P. ultimum. The root section of an infected root (Figure 5B) showed remarkable differences occurring mainly in a cross-section shape containing the epidermis, cortex, vascular cylinder and pith cells. Complete destruction was reported in several areas of the epidermis, separation and hydrolysis and eventually maceration in some area of cortex tissue and degradation and dissolution of pith cell components leading eventually to cell death and presence of black areas in the central part of the root cross section. Fungal growth hyphae could be clearly seen in the inter-and intera-cellular spaces of cortex tissue. While, the dimensions of xylem vessels were increased in infected root due to the plant's attempts at adaptating to compensate for the lack of water absorption. Otherwise, other treatments led to a decrease in the injurious effects of P. ultimumon root structure. The extract of chamomile flower was the most effective followed by the combination treatment of both $T$. harzianum and chamomile flower extract.
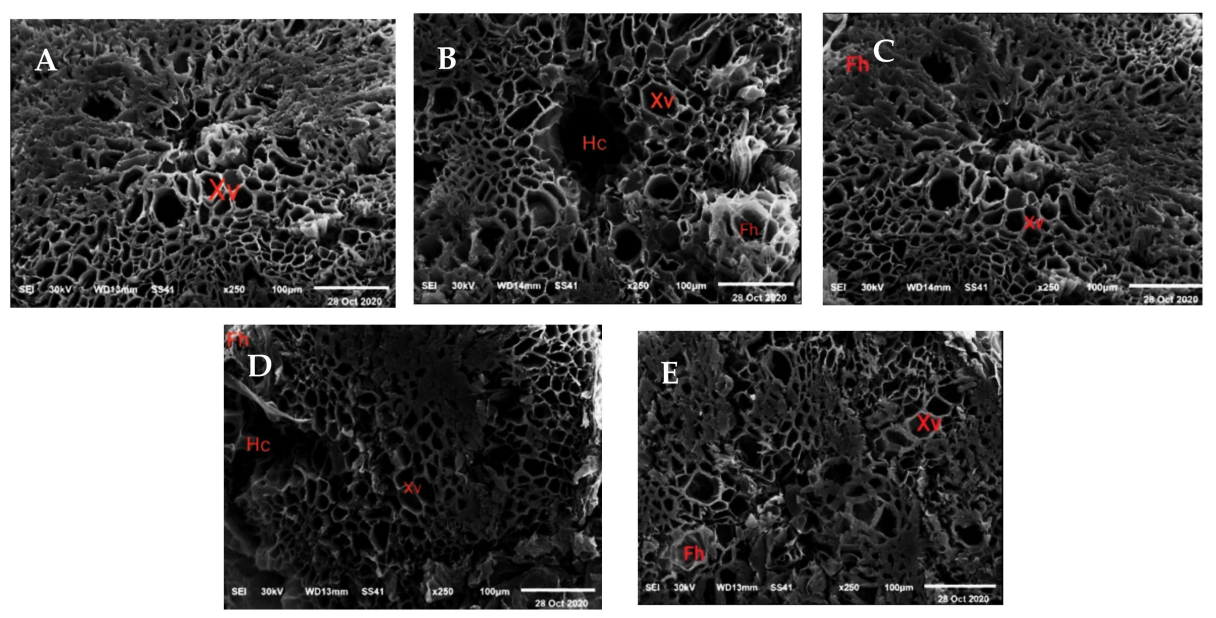

Figure 5. SEM micrograph of kidney bean root cross sections under infested soil with Pythium ultimum, (A): check (treated with fungicide), (B): fungal infection without treatment, $(\mathbf{C})$ : treated with extract + T. h., (D): treated with Trichoderma harzianum and (E): treated with extract. $\mathrm{X}_{\mathrm{v}}=\mathrm{Xylem}_{\mathrm{f}}$ vessels, $\mathrm{Hc}=$ hydrolyzed cells, $\mathrm{Fh}=$ Fungal hyphae.

Fungal infection causes anatomical changes in different plant organs such as the changes in parenchymatous cell walls which involve swelling, less of fibrillary wall, hydrolysis or dissolution of cell components and eventually maceration of the tissues due to an increase in ethylene production [54]. Ethylene promoted the activity of exo-and endo cellular hydrolytic enzymes i.e., pectinethylestrase, polyglacturonase and cellulose [55]. Moreover, El-Hai, et al. [56] showed deformation in the anatomical structure in the basal portion of soybean stem infected with M. phaseolina, R. solani, F. oxysporum and F. solani which occurred mainly in the epidermis, cortex and pith. They observed complete disruption in the epidermal cells and sever plasmolysis in the cortical cells with destruction of the outer cortical cells. The infected kidney bean by mixture pathogenic fungi (F. oxysporum, F. solani, R. solani and P. ultimum) led to complete destruction of the root epidermis and separation in some area of cortex tissue followed by degradation and dissolution of cell components [57]. In our investigation, the increase in the dimensions of xylem vessels in root cross sections under infection of P. ultimum might be because of the plant's attempts to compensate for the lack of water absorption which occurred due to the obstruction of some vessels by the fungal hyphae [58,59].

\section{Materials and Methods}

\subsection{Preparation of Matricaria Chamomilla Flower Extract}

Dry flowers of Matricaria chamomilla were obtained from the Agricultural Research Center (ARC, Giza, Egypt). Extraction process was prepared according to the method described by [60]. $100 \mathrm{~g}$ of Matricaria chamomilla whole dry flowers were extracted accurately 
using $1 \mathrm{~L}$ of deionized water heated to $60{ }^{\circ} \mathrm{C}$ for 90 min using a horizontal water bath shaker (Memmert WB14, Schwabach, Germany). Whatman no.1 filter paper (Whatman International Ltd., Kent, UK) was used to filter the extract. The filtrate was adjusted using deionized water in volumetric flasks to $500 \mathrm{~mL}$ and filtered through a Büchner funnel then stored at $-18^{\circ} \mathrm{C}$ for later use.

\subsection{Fractionation and Identification of Phenolic Compounds}

Phenolic compounds were identified using high performance liquid chromatography (HPLC) Technique at Food Technology Research Institute (FTRI), Agricultural Research Center according to Määttä, et al. [61]. This methodology was used for obtaining the chromatogram of each standard phenolic compound as well as a mixture of all the phenolic compounds. The standard phenolic compounds were purchased from reputed manufacturers such as Sigma-Aldrich (Cairo, Egypt). HPLC was conducted using a Hewlett-Packard instrument containing a 1100 series quaternary pump, diode array detector and an autosampler all linked to The Chemstation data handling system (Waldbronn Analytical Division, Waldbronn, Germany). Phenolic compounds were separated using LiChroCART Purospher RP-18e column $\left(125 \times 3 \mathrm{~mm}^{2}\right.$ i.d., $5 \mu \mathrm{m}$, Merck, Darmstadt, Germany) with a guard column of the same material $\left(4 \times 4 \mathrm{~mm}^{2}\right)$ used as protection. Finnigan MAT LCQ ion trap mass spectrometer (San Jose, CA, USA) with an attached Rheos 400 HPLC pump (Danderyd, Sweden) was used for Liquid chromatography-mass spectrometry (LC-MS) analysis. LC-MS is an analytical chemistry technique that combines the physical separation capabilities of liquid chromatography with the mass analysis capabilities of mass spectrometry. Conditions for the initial ionization in the positive and negative ionization modes included capillary voltages at $+4.5 \mathrm{kV}$ and $-3 \mathrm{kV}$ and a temperature at $225^{\circ} \mathrm{C}$. The MS data was acquired as full scan mass spectra at m/z 150-1500 by using $200 \mathrm{~ms}$ for collection of the ions in the trap. Tandem mass spectrometry or MS/MS is a technique in instrumental analysis where two mass analyzers are coupled together using an additional reaction step to increase their abilities to analyse chemical samples. MS/MS was performed using helium as the collision gas, and the collision energy was set at 30\%. MS revealed the positive or negative molecular ions; MS/MS broke down the most abundant ones with dependent collision-induced dissociation.

The percentage peak area method uses the area of the target component peak as a proportion of the total area of all detected peaks to analyze quantity. This method is used to determine changes in concentration of a known sample mixture, or to determine an approximate concentration of a sample mixture. Retention time and peak area were used to calculate the concentrations of phenolic compounds content compared with standard calibrated polyphenols by analyzing the data of Hewlett Packard software.

\subsection{Evaluation of Chamomile Flower Extracts Concentrations on Pythium Ultimum Growth}

The response of linear growth of Pythium ultimum to aqueous extract of chamomile (Matricaria chamomilla, L.) flower was evaluated. From the extract, four concentrations $(1.5 \%, 2.0 \%, 2.5 \%$ and $3.0 \%)$ were incorporated in potato dextrose broth media flasks by adding the appropriate amount of each concentration to the melted medium and then sterilized. Flasks without any addition were used as control. Disks ( $5 \mathrm{~mm}$ in diameter) taken from the growing edge of 5-day-old colony of Pythium were used singly inoculated the prepared flasks. The flasks were incubated at $\left(25^{\circ} \mathrm{C}\right)$. Three replicates were used per concentration. The fungal linear growth was calculated for three consecutive days from incubation.

\subsection{Antifungal activity of Trichoderma Harzianum}

- Dual Culture Assay

The potential of T. harzianum against P. ultimum was evaluated using a dual culture technique [62] by which the tested antagonist mycelial disc $(5 \mathrm{~mm})$ fungus was taken from 5-day-old culture which it paired against the same sized mycelial disc of pathogen 
fungus at the opposite end on $9 \mathrm{~cm}$ diameter of PDA Petri dishes. Both the pathogen and antagonist disc were inoculated at equal distances $(1 \mathrm{~cm})$ from the petri plate periphery. The PDA plates were incubated at $25 \pm 2{ }^{\circ} \mathrm{C}$. The growth of the pathogen and the control were recorded. The percent inhibition of radial growth was calculated using the following equation:

$$
\mathrm{I}=(\mathrm{R} 1-\mathrm{R} 2) / \mathrm{R} 1 \times 100
$$

where I = inhibition of radial growth. R1 = outward growth of the pathogen in control. $\mathrm{R} 2$ = radial growth of the pathogen in dual culture with antagonists.

Based on the previous screening, after five days of dual growth antagonism reaction of T. harzianum was evaluated by using a scale of five degrees, to detect growth and interaction between dual mycelia. The 1 to 5 scale rates the antagonism reaction, in which the first degree indicates that Trichoderma completely overgrowing pathogen and fifth degree is the opposite [63].

\subsection{Evaluation of M. Chamomilla Flower Extract Concentration on T. harzianum Linear Growth}

The effect of $2.0 \%, 2.5 \%$ and $3 \%$ concentration of $M$. chamomilla extract was evaluated on $T$. harzianum linear growth by incorporating in potato dextrose broth media flasks and then sterilized. Flasks without any addition were used as control. Disks ( $5 \mathrm{~mm}$ in diameter) taken from the growing edge of 5-day-old colony of T. harzianum were used to singly inoculated the prepared flasks and incubated at $\left(25^{\circ} \mathrm{C}\right)$. Three replicates were used per concentration. The fungal linear growth was calculated for three consecutive days from incubation. T. harzianum was filtrated, fresh and dry weight of mat was recorded with three replicates.

\subsection{Evaluation of Chamomile Flower Extract on T. harzianum Sporulation}

To investigate the enhancing of chamomile flower extract on T. harzianum, the fungus was gently scraped from the Petri-dish with a sharp spatula and washed several times with a total volume of $50 \mathrm{~mL}$ of sterilized water. The number of spores per $\mathrm{mL}$ was determined using a hemocytometer compared to the control.

\subsection{Greenhouse Experiment}

The effect of M. chamomilla flower extract and T. harzianum either each of them separately or in combination between them was evaluated against Pythium pathogen under greenhouse conditions.

\subsubsection{Inoculum Preparation}

- The inoculum of Pythium

P. ultimum inoculum was prepared by growing on potato dextrose agar plates and incubated at $25^{\circ} \mathrm{C}$ for five days and then mycelial plugs were carried on sterilizing medium of sorghum: coarse sand: water $(2: 1: 2 v / v)$ and incubated at $25^{\circ} \mathrm{C}$ for ten days; to be ready to use.

- T. harzianum inoculum

T. harzianum inoculum was prepared using 14 days old culture grown on potato dextrose broth under static conditions $(25 \pm 2)$ as active ingredients.

3.7.2. Greenhouse Evaluation of Chamomile Flower Extract and/or T. harzianum on Phaseolus vulgaris Pathogen

Pots were filled with $8 \mathrm{~kg} /$ pot antiseptic soil; clay: sand $(2: 1, v / v)$ and singly infested with the previous prepared pathogen inoculum at the rate of $0.4 \%(w / w)$, with irrigate regularly with tap water and left for one week to warranty the fungus spread. On the day of planting, the beans were soaked in $2.5 \%$ of $M$. chamomilla concentration and T. harzianum filtrate either each of them separately or in combination between them according to the 
treatment. Additionally, chemical fungicide (F) used was ( $56 \%$ Sc) Dose that recommended by the Ministry of Agricultural, was $250 \mathrm{~cm} / 100 \mathrm{~L}$.

The treatments applied were; (1) chamomile extract (2) T. harzianum (3) chamomile extract $+T$. harzianum, (4) Fungicide, (5) Pythium only, (6) chamomile extract + Pythium, (7) chamomile extract $+T$. harzianum + Pythium and (8) T. harzianum + Pythium. All pots were organized in randomized block design and kept in the greenhouse.

- Disease assessment

After ten days, the percentage of rotted beans (un-emerged beans), post infected seedlings (percentage of dead seedlings after 30 days from planting) and plant survival was recorded.

- Vegetative growth parameters

Five plants of each treatment were carefully harvested after five weeks from planting, rinsing with tap water to remove any soil particles and the following parameters were recorded, shoot, root and plant length $(\mathrm{cm})$, root fresh and dry weight $(\mathrm{g})$, plant fresh and dry weight $(\mathrm{g})$ and leaf area.

- Chlorophylls and carotenoids content of investigated leaves

The totals of the following, chlorophyll a, b and carotenoids were evaluated according to Wellburn [64]. Fresh leaves ( $0.05 \mathrm{~g})$ were placed inside a test tube, softened and soaked in $10 \mathrm{~mL}$ methanol at $4{ }^{\circ} \mathrm{C}$ overnight in the presence of trace amounts of sodium bicarbonate to inhibit the function of chlorophyllase enzymes, the test tube is then sealed using aluminum foil to prevent photooxidation from occurring. The chlorophyll contents were then measured through spectrophotometry at $452.5,650$ and $665 \mathrm{~nm}$ respectively using the following calculations [65]:

$$
\begin{aligned}
& \text { Total Chlorophyll }=(25.5 \times \text { E650 })+(4 \times \text { E665 }) \\
& \text { Chlorophyll } \mathrm{a}=(16.5 \times \text { E665 })-(8.3 \times \text { E650 }) \\
& \text { Chlorophyll b }=(33.8 \times \text { E650 })-(12.5 \times \text { E665 }) \\
& \text { Carotene }=(4.2 \times \text { E452.5 })-(0.0264 \times \text { Chlorophyll a })-(0.496 \times \text { Chlorophyll b }) \\
& \text { Chlorophyll or carotene }(\mathrm{mg} / \mathrm{g} \text { fresh weight) } \\
& =\frac{\text { Chlorophyll or carotene content } \times \text { volume of methanol }}{1000 \times \text { weight of sample }(\mathrm{g})}
\end{aligned}
$$

- Total polyphenols content

To measure the total phenolic content, $0.1 \mathrm{~g}$ of air-dried leaves were dissolved in $1 \mathrm{~mL}$ of distilled water of which $0.1 \mathrm{~mL}$ was taken and added to a solution of exactly $2.8 \mathrm{~mL}$ of distilled water, $2.0 \mathrm{~mL}$ of $2 \%(w / v)$ sodium carbonate and finally $0.1 \mathrm{~mL}$ of $50 \%(v / v)$ of FolinCiocalteu reagent utilizing the Folin-Ciocalteu reagent method [66]. The mixture was then incubated at room temperature for $30 \mathrm{~min}$ before the solution was spectrophotometrically (Spekol 11 spectrophotometer, Analytik Jena AG, Jena, Germany) measured at $750 \mathrm{~nm}$ with distilled water used as a blank. For quantitative assessment a standard curve of gallic acid $(0-200 \mathrm{mg} / \mathrm{L})$ was prepared in the same manner. Total phenol contents were expressed as milligram gallic acid equivalent (GAE)/g based on dry weight.

- Total flavonoids content

To measure the total flavonoids colorimetrically of the air-dried leaves, $0.1 \mathrm{~g}$ of the leaves were dissolved in $1 \mathrm{~mL}$ of distilled water of which $0.5 \mathrm{~mL}$ was then taken and $1.5 \mathrm{~mL}$ of $95 \%$ ethyl alcohol, $0.1 \mathrm{~mL}$ of $10 \%$ aluminum chloride $\left(\mathrm{AlCl}_{3}\right), 0.1 \mathrm{~mL}$ of $1 \mathrm{M}$ potassium acetate $\left(\mathrm{CH}_{3} \mathrm{COOK}\right)$ and $2.8 \mathrm{~mL}$ of distilled water was added [67]. The resulting solution was then incubated for $40 \mathrm{~m}$ at standard room temperature before the solution was measured using a spectrophotometer at $415 \mathrm{~nm}$ with distilled water used as a blank. A standard curve was constructed using quercetin as the standard for flavonoids $(0-50 \mathrm{mg} / \mathrm{L})$. 
The total concentration of the flavonoids contents were measured as milligram quercetin equivalent $(\mathrm{QE}) / \mathrm{g}$ based on dry weight.

- Determination of antioxidant activity by the DPPH and ABTS radicals scavenging methods

The free radical scavenging activity was determined according to [68] using different concentrations of 2,2-diphenyl-1-picrylhydrazyl (DPPH) by measuring the bleaching of the purple color of DPPH, the absorbance was measured at $517 \mathrm{~nm}$ and the percentage of inhibition was calculated. The ABTS (2,2'-azino-bis (3-ethyl benzothiazoline-6-sulfonic acid) assay was based on the method of Christodouleas, et al. [68]. The absorbance of the resulting greenish-blue solution was recorded at wavelength $734 \mathrm{~nm}$, the decrease in the absorbance is expressed as a percentage of inhibition which was calculated.

- Polyphenol oxidase and peroxidase activities

Extraction and activity of both enzymes were determined using a spectrophotometric method based on an initial rate of increase in absorbance at $410 \mathrm{~nm}$ were carried out at $4{ }^{\circ} \mathrm{C}$, according to Seleim, et al. [69].

\subsection{SEM Analysis}

The anatomical changes in bean root due to the pathogen and other treatments were studied by taking cross sections, gold-coating them and examining at various magnifications using SEM (TEM-2100, JEOL, Tokyo, Japan) attached to an accelerating voltage of $200 \mathrm{kV}$ at the Central Laboratory, Electron Microscope Unit, Mansoura University, Egypt [70].

\subsection{Statistical Analysis}

The statistical analysis software CoStat version 6.4 (CoHort Software, Pacific Grove, CA, USA) was used to perform the analysis of variance of the data. Duncan's new multiple range test at probability $(p)$ level $\leq 0.05$ was applied. Some of the experimental data were presented as means \pm standard deviation $( \pm S D)$ and at least six replicates were used.

\section{Conclusions}

Our investigative study aimed to investigate the effect of chamomile (Matricaria chamomilla, L.) flower extract and T. harzianum either alone or combined as bioagents against $P$. ultimum with an effect up to $30-81.6 \%$ radial growth reduction in both of in vitro and in vivo applications. The potentiality of both chamomile extract and T. harzianum against P. ultimum was obtained. Furthermore, the fractionation of $M$. chamomilla extract was performed to investigate its active compounds which showed several polyphenolic compounds. The in vivo response of percentages of root rot, seedling rot and survival for both chamomile flower extract and T. harzianum was determined to be up by $64 \%$. The biochemical parameters such as chlorophyll, carotenoids, and antioxidant enzymes increased with use of the therapeutic treatments and the cross sections of roots of bean were investigated using SEM with a decrease in symptomatic features of diseases as a response of therapeutic treatments. In conclusion, the application of both T. harzianum and/or M. chamomilla extracts in the control of bean Pythium pathogen showed significant results.

Author Contributions: A.A.G., K.M.A.E.-H., A.Y.E.-k., N.M.E., S.F.M. and A.E. suggested the work protocol, performed the laboratory experiments, interpreted the results, prepared and revised the manuscript. All authors have read and agreed to the published version of the manuscript.

Funding: This research received no external funding.

Institutional Review Board Statement: Not applicable as our studies did not involve humans.

Informed Consent Statement: Not applicable as our studies did not involve humans.

Data Availability Statement: See MDPI Research Data Policies at https:/ /www.mdpi.com/ethics. 
Acknowledgments: The authors thank Taif University Researchers Supporting Project number (TURSP-2020/138) for supporting this study, Taif University, Taif, Saudi Arabia.

Conflicts of Interest: The authors declare no conflict of interest.

Sample Availability: Samples of the compounds are not available from the authors.

\section{References}

1. Binagwa, P.H.; Bonsi, C.K.; Msolla, S.N. Evaluation of common bean (Phaseolus vulgaris) genotypes for resistance to root rot disease caused by Pythium aphanidermatum and Pythium splendens under screen house conditions. J. Nat. Sci. Res. 2016, 6, 36-43.

2. Kiptoo, G.J.; Kinyua, M.G.; Kiplagat, O.K. Evaluation of phenolic content of common bean (Phaseolus vulgaris L.) in association to bean fly (Ophiomyia spp.) infestation. Int. J. Agron. Agric. Res. 2019, 14, 9-13.

3. Devi, M.; Dhanalakshmi, S.; Govindarajan, G.T.; Tanisha, B.; Sonalika, T.; Ruth, J.; Avinash, T.; Sri, C.J.; Logeswaran, K.; Ramasamy, M.N. A Review on Phaseolus vulgaris Linn. Pharmacogn. J. 2020, 12. [CrossRef]

4. Schwartz, H.F.; Steadman, J.R.; Hall, R.; Forster, R.L. Compendium of Bean Diseases; American Phytopathological Society (APS Press): Sherman, CT, USA, 2005.

5. Al-Mahmooli, I.; Al-Fahdi, A.; Al-Sadi, A.; Deadman, M. First report of root rot and crown necrosis caused by Pythium aphanidermatum on Phaseolus vulgaris in Oman. Dis. Notes 2015, 99, 419. [CrossRef]

6. Haritha, V.; Gopal, K.; Madhnsudhan, P.; Viswanath, K.; Rao, S. Integrated Management of Damping-off Disease Incited by Pythium aphanidermatum (Edson) Fitzp. in Tobacco Nursery. Plant Dis. Sci. 2010, 5, 41-47.

7. Kilany, M.; Ibrahim, E.H.; Al Amry, S.; Al Roman, S.; Siddiqi, S. Microbial suppressiveness of Pythium damping-Off diseases. In Organic Amendments and Soil Suppressiveness in Plant Disease Management; Springer: Zurich, Switzerland, 2015; pp. 187-206.

8. Mukuma, C.; Godoy-Lutz, G.; Eskridge, K.; Steadman, J.; Urrea, C.; Muimui, K. Use of culture and molecular methods for identification and characterization of dry bean fungal root rot pathogens in Zambia. Trop. Plant Pathol. 2020, 45, 385-396. [CrossRef]

9. Lucas, B.; Griffiths, P.D. Evaluation of common bean accessions for resistance to Pythium ultimum. HortScience 2004, 39, 1193-1195. [CrossRef]

10. Abeysinghe, S. Systemic resistance induced by Trichoderma harzianum RU01 against Uromyces appendiculatus on Phaseolus vulgaris. J. Natl. Sci. Found. Sri Lanka 2009, 37. [CrossRef]

11. Mukhopadhyay, A.N. Biological control of soil borne plant pathogens by Trichoderma spp. Indian J. Mycol. Pathol. 1987, 17, 1-10.

12. Boughalleb-M'Hamdi, N.; Salem, I.B.; M'Hamdi, M. Evaluation of the efficiency of Trichoderma, Penicillium, and Aspergillus species as biological control agents against four soil-borne fungi of melon and watermelon. Egypt. J. Biol. Pest Control 2018, 28, 1-12.

13. Harman, G.E.; Howell, C.R.; Viterbo, A.; Chet, I.; Lorito, M. Trichoderma species—opportunistic, avirulent plant symbionts. Nat. Rev. Microbiol. 2004, 2, 43-56. [CrossRef] [PubMed]

14. Metcalf, D.; Wilson, C. The process of antagonism of Sclerotium cepivorum in white rot affected onion roots by Trichoderma koningii. Plant Pathol. 2001, 50, 249-257. [CrossRef]

15. Negi, S.; Bharat, N.K.; Kaushal, R.; Rohiwala, P. Screening of bioagents for seed biopriming in French bean (Phaseolus vulgaris L.) under Laboratory condition. IJCS 2020, 8, 790-793. [CrossRef]

16. Howell, C. Cotton seedling preemergence damping-off incited by Rhizopus oryzae and Pythium spp. and its biological control with Trichoderma spp. Phytopathology 2002, 92, 177-180. [CrossRef] [PubMed]

17. Maheshwary, N.; Gangadhara Naik, B.; Amoghavarsha Chittaragi, M.; Naik, S.K.; Nandish, M. Compatibility of Trichoderma asperellum with fungicides. Pharma Innov. J. 2020, 9, 136-140.

18. Ghisalberti, E.; Sivasithamparam, K. Biochemistry, Antifungal antibiotics produced by Trichoderma spp. Soil Biol. Biochem. 1991, 23, 1011-1020. [CrossRef]

19. Ahmed, M.; El-Fiki, I. Effect of biological control of root rot diseases of strawberry using Trichoderma spp. Middle East J. Appl. Sci. 2017, 7, 482-492.

20. Hasan, M.F.; Islam, M.A.; Sikdar, B. Evaluation of possible biological control of Fusarium sp. using plant extracts and antagonistic species of microbes in vitro. Eur. PMC Plus 2020, 9, 1394. [CrossRef]

21. Kalemba, D.; Kunicka, A. Antibacterial and antifungal properties of essential oils. Curr. Med. Chem. 2003, 10, 813-829. [CrossRef]

22. Orlikowski, L.; Skrzypczak, C. Biocides in the control of soil-borne and leaf pathogens. Ital. J. Agron. 2003, 22, 426-433.

23. Putnik, P.; Bursać Kovačević, D.; Režek Jambrak, A.; Barba, F.J.; Cravotto, G.; Binello, A.; Lorenzo, J.M.; Shpigelman, A. Innovative "green" and novel strategies for the extraction of bioactive added value compounds from citrus wastes-A review. Molecules 2017, 22, 680. [CrossRef]

24. Akkari, H.; B'chir, F.; Hajaji, S.; Rekik, M.; Sebai, E.; Hamza, H.; Darghouth, M.; Gharbi, M. Potential anthelmintic effect of Capparis spinosa (Capparidaceae) as related to its polyphenolic content and antioxidant activity. Vet. Med. 2016, 61, 308-316. [CrossRef]

25. Najjaa, H.; Abdelkarim, B.A.; Doria, E.; Boubakri, A.; Trabelsi, N.; Falleh, H.; Tlili, H.; Neffati, M. Phenolic composition of some Tunisian medicinal plants associated with anti-proliferative effect on human breast cancer MCF-7 cells. EuroBiotech. J. 2020, 4, 104-112. [CrossRef] 
26. Žlabur, J.Š.; Žutić, I.; Radman, S.; Pleša, M.; Brnčić, M.; Barba, F.J.; Rocchetti, G.; Lucini, L.; Lorenzo, J.M.; Domínguez, R. Effect of different green extraction methods and solvents on bioactive components of chamomile (Matricaria chamomilla L.) flowers. Molecules 2020, 25, 810. [CrossRef]

27. Raal, A.; Orav, A.; Püssa, T.; Valner, C.; Malmiste, B.; Arak, E. Content of essential oil, terpenoids and polyphenols in commercial chamomile (Chamomilla recutita L. Rauschert) teas from different countries. Food Chem. 2012, 131, 632-638. [CrossRef]

28. Sotiropoulou, N.S.; Megremi, S.F.; Tarantilis, P. Evaluation of antioxidant activity, toxicity, and phenolic profile of aqueous extracts of chamomile (Matricaria chamomilla L.) and sage (Salvia officinalis L.) prepared at different temperatures. Appl. Sci. 2020, 10, 2270. [CrossRef]

29. Da Silva Pinto, M. Tea: A new perspective on health benefits. Food Res. Int. 2013, 53, 558-567. [CrossRef]

30. Jiang, T.; Zhan, S.; Li, S.; Zhu, Z.; He, J.; Lorenzo, J.M.; Barba, F.J. From 'green'technologies to 'red'antioxidant compounds extraction of purple corn: A combined ultrasound-ultrafiltration-purification approach. J. Sci. Food Agric. 2018, 98, 4919-4927. [CrossRef] [PubMed]

31. Landeka Jurčević, I.; Dora, M.; Guberović, I.; Petras, M.; Rimac Brnčić, S.; Đikić, D. Polyphenols from wine lees as a novel functional bioactive compound in the protection against oxidative stress and hyperlipidaemia. Food Technol. Biotechnol. 2017, 55, 109-116. [CrossRef] [PubMed]

32. Agregan, R.; Munekata, P.E.; Franco, D.; Dominguez, R.; Carballo, J.; Lorenzo, J.M. Phenolic compounds from three brown seaweed species using LC-DAD-ESI-MS/MS. Food Res. Int. 2017, 99, 979-985. [CrossRef]

33. Meziadi, C.; Richard, M.M.; Derquennes, A.; Thareau, V.; Blanchet, S.; Gratias, A.; Pflieger, S.; Geffroy, V. Development of molecular markers linked to disease resistance genes in common bean based on whole genome sequence. Plant Sci. 2016, 242, 351-357. [CrossRef]

34. Sendi, Y.; Pfeiffer, T.; Koch, E.; Mhadhbi, H.; Mrabet, M. Potential of common bean (Phaseolus vulgaris L.) root microbiome in the biocontrol of root rot disease and traits of performance. J. Plant Dis. Prot. 2020, 127, 453-462. [CrossRef]

35. Martins, S.A.; Schurt, D.A.; Seabra, S.S.; Martins, S.J.; Ramalho, M.A.P.; de Souza Moreira, F.M.; da Silva, J.C.P.; da Silva, J.A.G.; de Medeiros, F.H.V. Common bean (Phaseolus vulgaris L.) growth promotion and biocontrol by rhizobacteria under Rhizoctonia solani suppressive and conducive soils. Appl. Soil Ecol. 2018, 127, 129-135. [CrossRef]

36. Ellis, C.; Karafyllidis, I.; Turner, J.G. Constitutive activation of jasmonate signaling in an Arabidopsis mutant correlates with enhanced resistance to Erysiphe cichoracearum, Pseudomonas syringae, and Myzus persicae. Mol. Plant Microbe Interact. 2002, 15, 1025-1030. [CrossRef] [PubMed]

37. Lingk, W. Health risk evaluation of pesticide contaminations in drinking water. Occup. Dis. Environ. Med. 1991, 6, 119-129. [CrossRef]

38. Surekha, C.; Neelapu, N.; Kamala, G.; Prasad, B.S.; Ganesh, P.S. Efficacy of Trichoderma viride to induce disease resistance and antioxidant responses in legume Vigna mungo infested by Fusarium oxysporum and Alternaria alternata. Int. J. Agric. Sci. Res. 2013, 3, 285-294.

39. Gajera, H.P.; Bambharolia, R.P.; Patel, S.V.; Khatrani, T.J.; Goalkiya, B.A. Antagonism of Trichoderma spp. against Macrophomina phaseolina: Evaluation of coiling and cell wall degrading enzymatic activities. J. Plant Pathol. Microb. 2012, 3-7. [CrossRef]

40. Nasir Hussein, A.; Abbasi, S.; Sharifi, R.; Jamali, S. The effect of biocontrol agents consortia against Rhizoctonia root rot of common bean Phaseolus vulgaris. J. Crop Prot. 2018, 7, 73-85.

41. Rajkonda, J.; Sawant, V.; Ambuse, M.; Bhale, U. Inimical potential of Trichoderma species against pathogenic fungi. Plant Sci. Feed. 2011, 1, 10-13.

42. El-Khateeb, N.M.; Nehela, Y. The dual inoculation with Rhizobium sp. and cyanobacterial extracts enhances the common bean (Phaseolus vulgaris L.) responses to white rot disease caused by Sclerotinia sclerotiorum. Middle East J. Appl. Sci. $2019,872-887$.

43. Jones, E.; Stewart, A. Biological control of Sclerotinia minor in lettuce using Trichoderma species. In Proceedings of the New Zealand Plant Protection Conference, Canterbury, New Zealand, 19 August 1997; pp. 154-158. [CrossRef]

44. McLean, K.; Hunt, J.; Stewart, A. Compatibility of the biocontrol agent Trichoderma harzianum C52 with selected fungicides. N. Z. Plant Prot. 2001, 54, 84-88. [CrossRef]

45. Ghoniem, A.A.; Rashad, E.M.; El-Khateeb, A.Y.; Saber, W.I. Bacteriological Therapeutic-Based Strategy for Management of Fusarium Wilt Disease in Tomato Plants. Available online: https:/ /www.semanticscholar.org/paper/Bacteriological-TherapeuticBased-Strategy-for-of-Ghoniem-Rashad/517b4554902636dda3f4bdcb4e3f42b15a93f986 (accessed on 22 February 2021).

46. Agamy, R.; Alamri, S.; Moustafa, M.F.; Hashem, M. Management of tomato leaf spot caused by Alternaria tenuissima Wiltshire using salicylic acid and agrileen. Int. J. Agric. Biol. 2013, 15, 266-272.

47. Al-Askar, A.; Ezzat, A.; Ghoneem, K.; Saber, W.J.E. Trichoderma harzianum WKY5 and its Gibberellic Acid Control of Rhizoctonia solani, Improve Sprouting, Growth and Productivity of Potato. Egypt. J. Biol. 2016, 26, 787-796.

48. Hoyos-Carvajal, L.; Orduz, S.; Bissett, J. Growth stimulation in bean (Phaseolus vulgaris L.) by Trichoderma. Biol. Control 2009, 51, 409-416. [CrossRef]

49. Yu, T.; Zheng, X.D. Salicylic acid enhances biocontrol efficacy of the antagonist Cryptococcus laurentii in apple fruit. J. Plant Growth Regul. 2006, 25, 166-174. [CrossRef]

50. Raats, P. Effect of Trichoderma species on damping off diseases incidence, some plant enzymes activity and nutritional status of bean plants. J. Am. Sci. 2012, 2, 13-25. 
51. Gajera, H.; Domadiya, R.; Patel, S.; Kapopara, M.; Golakiya, B. Molecular mechanism of Trichoderma as bio-control agents against phytopathogen system-a review. Curr. Res. Microbiol. Biotechnol. 2013, 1, 133-142.

52. Vinale, F.; Sivasithamparam, K.; Ghisalberti, E.L.; Woo, S.L.; Nigro, M.; Marra, R.; Lombardi, N.; Pascale, A.; Ruocco, M.; Lanzuise, S. Trichoderma secondary metabolites active on plants and fungal pathogens. Open Mycol. J. 2014, 8, 127-139. [CrossRef]

53. Kredics, L.; Manczinger, L.; Antal, Z.; Pénzes, Z.; Szekeres, A.; Kevei, F.; Nagy, E.J. In vitro water activity and pH dependence of mycelial growth and extracellular enzyme activities of Trichoderma strains with biocontrol potential. J. Appl. Microbiol. 2004, 96, 491-498. [CrossRef]

54. Beck, C.B. An Introduction to Plant Structure and Development: Plant Anatomy for the Twenty-First Century; Cambridge University Press: Cambridge, UK, 2010.

55. El-Samra, I.; Noman, K.; Fayed, M.; El-Farnawany, M.J. Studies on some histopathological and enzymatic activity aspects during the Rhizoctonia damping-off disease of beans. J. Agric. Sci. Mansoura Univ. Egypt 1994, 10, 2209-2225.

56. El-Hai, K.; El-Metwally, M.; El-Baz, S. Reduction of soybean root and stalk rots by growth substances under salt stress conditions. Plant. Pathol. J. 2010, 9, 149-161. [CrossRef]

57. El-Hai, A.; Ali, A.A. Amelioration of the Structural and Biochemical Features of Kidney Bean against Root Rot and Rust Diseases. J. Plant Prot. Pathol. 2018, 9, 237-245.

58. Yadeta, K.; Thomma, B. The xylem as battleground for plant hosts and vascular wilt pathogens. Front Plant Sci. $2013,4,97$. [CrossRef]

59. Ploetz, R.C.; Kendra, P.E.; Choudhury, R.A.; Rollins, J.A.; Campbell, A.; Garrett, K.; Hughes, M.; Dreaden, T. Laurel wilt in natural and agricultural ecosystems: Understanding the drivers and scales of complex pathosystems. Forests 2017, 8, 48. [CrossRef]

60. Dent, M.; Dragović-Uzelac, V.; Penić, M.; Bosiljkov, T.; Levaj, B. The effect of extraction solvents, temperature and time on the composition and mass fraction of polyphenols in Dalmatian wild sage (Salvia officinalis L.) extracts. Food Technol. Biotechnol. 2013, 51, 84-91.

61. Määttä, K.R.; Kamal-Eldin, A.; Törrönen, A.R. High-performance liquid chromatography (HPLC) analysis of phenolic compounds in berries with diode array and electrospray ionization mass spectrometric (MS) detection: Ribes species. J. Agric. Food Chem. 2003, 51, 6736-6744. [CrossRef] [PubMed]

62. Dhingra, O.; Sinclair, J. Basic Plant Pathology Methods, 2nd ed.; Lewis Publishers: Boca Raton, FL, USA, 1995.

63. Bell, D.; Wells, H.; Markham, C. In vitro antagonism of Trichoderma species against six fungal plant pathogens. Phytopathology 1982, 72, 379-382. [CrossRef]

64. Wellburn, A.R. The spectral determination of chlorophylls a and b, as well as total carotenoids, using various solvents with spectrophotometers of different resolution. J. Plant Physiol. 1994, 144, 307-313. [CrossRef]

65. Mackinney, G. Absorption of light by chlorophyll solutions. J. Biol. Chem. 1941, 140, 315-322. [CrossRef]

66. Blainski, A.; Lopes, G.C.; De Mello, J.C. Application and analysis of the folin ciocalteu method for the determination of the total phenolic content from Limonium brasiliense L. Molecules 2013, 18, 6852-6865. [CrossRef]

67. Das, S.; Ray, A.; Nasim, N.; Nayak, S.; Mohanty, S. Effect of different extraction techniques on total phenolic and flavonoid contents, and antioxidant activity of betelvine and quantification of its phenolic constituents by validated HPTLC method. 3 Biotech 2019, 9, 37. [CrossRef] [PubMed]

68. Christodouleas, D.C.; Fotakis, C.; Nikokavoura, A.; Papadopoulos, K.; Calokerinos, A.C. Modified DPPH and ABTS assays to assess the antioxidant profile of untreated oils. Food Anal. Methods 2015, 8, 1294-1302. [CrossRef]

69. Seleim, M.; Abo-Elyousr, K.; Mohamed, A.; Al-Marzoky, H. Peroxidase and polyphenoloxidase activities as biochemical markers for biocontrol efficacy in the control of tomato bacterial wilt. J. Plant Physiol. Pathol. 2014, 2, 2-8. [CrossRef]

70. Caldwell, D.; Iyer-Pascuzzi, A.S. A Scanning Electron Microscopy Technique for Viewing Plant-Microbe Interactions at Tissue and Cell-Type Resolution. Phytopathology 2019, 109, 1302-1311. [CrossRef] [PubMed] 